\title{
ANALISA PRODUKTIVITAS KELAPA SAWIT DI DATARAN TINGGI KEBUN BAH BIRONG ULU-PT. PERKEBUNAN NUSANTARA IV
}

\author{
Tuty Ningsih ${ }^{1}$, Rina Maharany ${ }^{1}$, Sukri Khoirul Fu'adh ${ }^{2}$ \\ E-mail : tutyningsih114@,gmail.com
}

\begin{abstract}
ABSTRAK
Secara umum, persyaratan untuk menanam kelapa sawit pada ketinggian $\quad 0-400 \mathrm{~m}$ di atas permukaan laut. Tingginya permintaan Minyak Sawit Mentah di pasar internasional telah menyebabkan pemerintah memperluas perkebunan kelapa sawit ke ketinggian tinggi. Budidaya kelapa sawit di dataran tinggi akan mempengaruhi tingkat produksi dan produktivitas. Penelitian ini dilakukan di Perkebunan Bah Birong Ulu PT. Perkebunan Nusantara IV dari Januari hingga September 2019. Metode penelitian yang digunakan adalah metode deskriptif kualitatif. Hasil penelitian menunjukkan bahwa (1) produktivitas kelapa sawit tertinggi pada 2017 adalah 1.280 ton/ha/tahun dan produktivitas terendah pada 2015 adalah 1.071 ton/ha/tahun. (2) Realisasi produksi untuk TBS kelapa sawit dan RJT lebih rendah dibandingkan dengan potensi produksi. Padahal realisasi produksi untuk RBT lebih tinggi jika dibandingkan dengan potensi produksi.
\end{abstract}

\section{Analysis of Palm Oil Productivity In High Altitude Bah Birong Ulu Garden PT. Perkebunan Nusantara IV}

\section{ABSTRACT}

In general, the requirements for growing oil palm plants at an altitude of $0-400 \mathrm{~m}$ above sea level. The high demand for Crude Palm Oil in the international market has caused the government to expand oil palm plantations to the high altitude. Oil palm cultivation in the high altitude will affect the level of production and productivity. This research was carried out at Bah Birong Ulu Plantation PT. Perkebunan Nusantara IV from January to September 2019. The research method used is a descriptive qualitative method. The results showed that (1) the highest oil palm productivity in 2017 was 1,280 tons/ha/yr and the lowest productivity in 2015 was 1,071 tons/ha/yr. (2) The realization of production for oil palm FFB and RJT is lower compared to production potential. Whereas the production realization for RBT is higher when compared to the production potential.

\section{PENDAHULUAN}

Tanaman kelapa sawit merupakan salah satu komoditas perkebunan yang sangat unggul memiliki luas areal terbesar di dunia. Luas areal perkebunan kelapa sawit di Indonesia pada tahun 2016 mencapai 11.672.861 ha dan menghasilkan produksi sebanyak $33.229,381$ ton CPO pada tahun tersebut (Direktorat Jenderal Perkebunan, 2016). Ekspansi kebun kelapa sawit memberikan dampak ekonomi, lingkungan, dan pengembangan industri CPO. Kontribusi industri berbasis kelapa sawit mempunyai peranan penting dalam pertumbuhan ekonomi, pengentasan kemiskinan, dan perbaikan distribusi pendapatan. Pengembangan kelapa sawit berdampak positif terhadap pertumbuhan ekonomi yang ditunjukkan oleh pertumbuhan investasi, output, dan devisa. Industri berbasis kelapa sawit juga 
mempunyai kontribusi signifikan terhadap kesejahteraan rumah tangga yang berasal dari usaha kelapa sawit (Susila, 2004).

Kelapa sawit di Indonesia pada dataran tinggi (altitude $>600$ Meter Diatas Permukaan Laut (m dpl) mulai dilakukan pada tahun 1996 di Kebun Bah Birong Ulu, Sumatera Utara. Penanaman kelapa sawit di dataran tinggi sampai dengan 850 mdpl dimungkinkan karena faktor pembatas utama telah berubah yaitu terjadi penigkatan rata-rata temperatur udara minimum menjadi $18^{\circ} \mathrm{C}$ sejak tahun 1990 , namun temperatur minimum bulan $<18^{\circ} \mathrm{C}$ masih berpeluang terjadi pada bulan Desember - Januari. Hal ini tentu saja berpengaruh terhadap produksi kelapa sawit di dataran tinggi (Simangunsong $d k k ., 2005)$

\section{HASIL DAN PEMBAHASAN}

\section{Luas Areal}

Tabel 1. Data Luas Areal Afdeling I Kebun Bah Birong Ulu PTPN IV

\begin{tabular}{|c|c|c|c|c|}
\hline \multicolumn{5}{|c|}{ DATA AREAL AFDELING I BAH BIRONG ULU PTPN IV } \\
\hline $\begin{array}{l}\text { TAHUN } \\
\text { TANAM }\end{array}$ & $\begin{array}{c}\text { LUAS } \\
(\mathrm{Ha})\end{array}$ & $\begin{array}{c}\text { JUMLAH } \\
\text { POKOK }\end{array}$ & $\begin{array}{c}\mathrm{SPH} \\
(\mathrm{PKK} / \mathrm{Ha})\end{array}$ & JENIS KLON \\
\hline 2004 & 91 & 9,262 & 102 & PPKS \\
\hline 2005 & 374 & 38,415 & 103 & PPKS \\
\hline 2005 & 393 & 38,994 & 99 & SOCFIN \\
\hline 2006 & 13 & 1,717 & 132 & PPKS \\
\hline TOTAL & 871 & 88,388 & & \\
\hline
\end{tabular}

Tabel 1 menunjukkan bahwa luas areal afdeling I sebesar $871 \mathrm{Ha}$, dengan jumlah pokok tahaman sebanyak 88 pokok dan sebahagian besar bibit berasal dari PPKS (Pusat Penelitian Kelapa Sawit).

\section{Curah Hujan}

Curah hujan merupakan ketinggian air hujan yang terkumpul dalam tempat yang datar, tidak menguap, tidak meresap, dan tidak mengalir. Satuan curah hujan selalu dinyatakan dalam satuan milimeter atau inchi namun untuk di indonesia satuan

\section{METODE PENELITIAN}

Penelitian dilaksanakan di Kebun Bah Birong Ulu PT. Perkebunan Nusantara IV. Waktu pelaksaan dilaksanakan pada bulan Januari - September 2019. Metode yang digunakan dalam penelitian ini adalah metode analisa deskriptif kualitatif dengan mengumpulkan data di lokasi penelitian di Afdeling I Kebun Bah Birong Ulu PT. Perkebunan Nusantara IV.

Pengamatan dari penelitian ini adalah Informasi umum kebun meliputi sejarah dan peta kebun, Data produksi kelapa sawit Afdeling I dari tahun $2014 \mathrm{~s} / \mathrm{d}$ 2018, Data umur tanaman Afdeling I dari tahun 2014 s/d 2018, Luas lahan dan data curah hujan. curah hujan yang digunakan adalah dalam satuan milimeter (mm).

Curah hujan yang merata dapat menurunkan penguapan dari tanah dan tanaman kelapa sawit. Namun, yang terpenting adalah tidak terjadi defisit air diatas $250 \mathrm{~mm}$. Bila tanah dalam keadaan kering, akar tanaman sulit menyerap mineral dari dalam tanah. Oleh sebab itu, musim kemarau yang berkepanjangan cenderung akan menurunkan produksi (Fauzi $d k k$, 2012). 


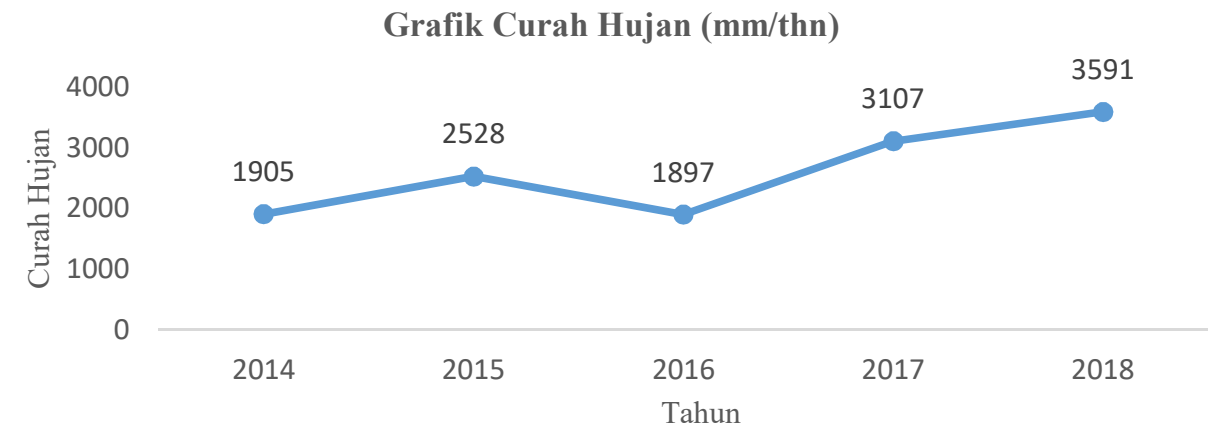

Gambar 1. Data Curah Hujan Afdeling I kebun Bah Birong Ulu PTPN IV Mulai Tahun $2014-2018$

Gambar 1 menunjukkan bahwa curah hujan terendah terdapat pada tahun 2016 yaitu sebanyak $1897 \mathrm{~mm} / \mathrm{tahun}$, dan curah hujan tertinggi terdapat pada tahun 2018 yaitu sebanyak $3591 \mathrm{~mm} /$ tahun.

\section{Produksi}

Produksi adalah kemampuan kelapa sawit dalam menghasilkan TBS (Tandan Buah Segar) yang diperoleh pada saat pelaksanaan pemanenan. Jumlah produksi sangat dipengaruhi oleh curah hujan, iklim, tofografi, suhu, dosis dan teknik pemupukan, penggunaan herbisida dan lain sebagainya. Kebun bah birong ulu merupakan daerah dataran tinggi yang berada pada kesesuaian lahan kelas S3 yaitu lahan yang mempunyai faktor pembatas sedang, lebih dari satu faktor pembatas ini akan sangat berpengaruh terhadap produktivitasnya, faktor pembatas memiliki berntuk wilayah berbukit dengan kelas drainase terhambat sehingga memelukan tambahan masukan yang lebih banyak dari pada lahan tergolong S2. Untuk mengatasi faktor pembatas pada S3 memerlukan modal tinggi, sehingga perlu adanya bantuan atau campur tangan (investasi) pemerintah atau pihak swasta.

Total Produksi Periode 2014-2018

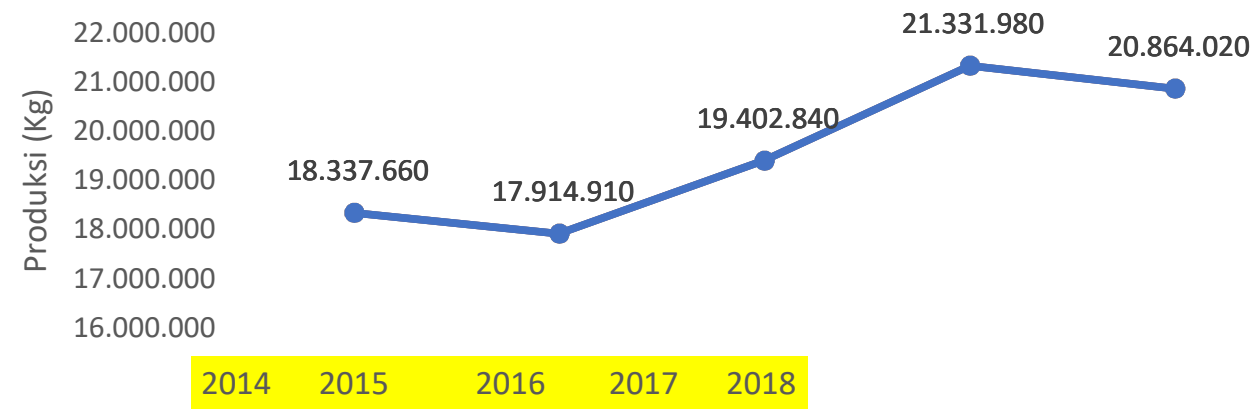

Gambar 2. Data Produksi Tandan Buah Segar (TBS) Afdeling I Kebun Bah Birong Ulu Mulai Tahun $2014-2018$

Gambar 2 menunjukan bahwa produksi TBS tertinggi terdapat pada tahun
2017 yaitu sebesar 21.331.980 kg, sedangkan produksi TBS yang terendah 
terdapat pada tahun 2015 yaitu sebesar $17.914 .910 \mathrm{~kg}$. Salah satu penyebab tinggi rendahnya produksi TBS adalah curah hujan. Pada tahun 2014, jumlah curah hujan di afdeling I adalah $1905 \mathrm{~mm} /$ tahun dengan hari hujan sebanyak 18 hari (dibawah curah hujan optimum).

Menurut Fauzi dkk (2012), curah hujan optimum rata-rata yang diperlukan tanaman kelapa sawit adalah 2.000-2.500 $\mathrm{mm} /$ tahun dengan distribusi merata sepanjang tahun tanpa bulan kering (defisit air) yang berkepanjangan. Curah hujan tersebut akan mempengaruhi produksi ditahun berikutnya. Jika curah hujan ditahun sebelumnya tidak optimum maka produksi akan menurun. Tahun 2016 curah hujan sebanyak $1897 \mathrm{~mm} /$ tahun dengan hari hujan sebanyak 106 hari. Meskipun jumlah curah hujan belum optimum tetapi distribusinya merata sepanjang tahun, sehingga menyebabkan produksi kelapa sawit tahun 2017 berada pada fase tertinggi.

\section{Produktivitas}

Produktivitas tanaman kelapa sawit dipengaruhi oleh umur tanaman. Tanaman tua berumur lebih dari 15 tahun memiliki tandan yang lebih berat dibandingkan dengan tanaman yang muda. Untuk kelapa sawit yang berumur di atas 10 tahun, berat tandan rata-rata sama untuk setiap tahunnya. Semakin tinggi kandungan unsur hara di dalam tanah, semakin tinggi juga produktivitas kelapa sawit.

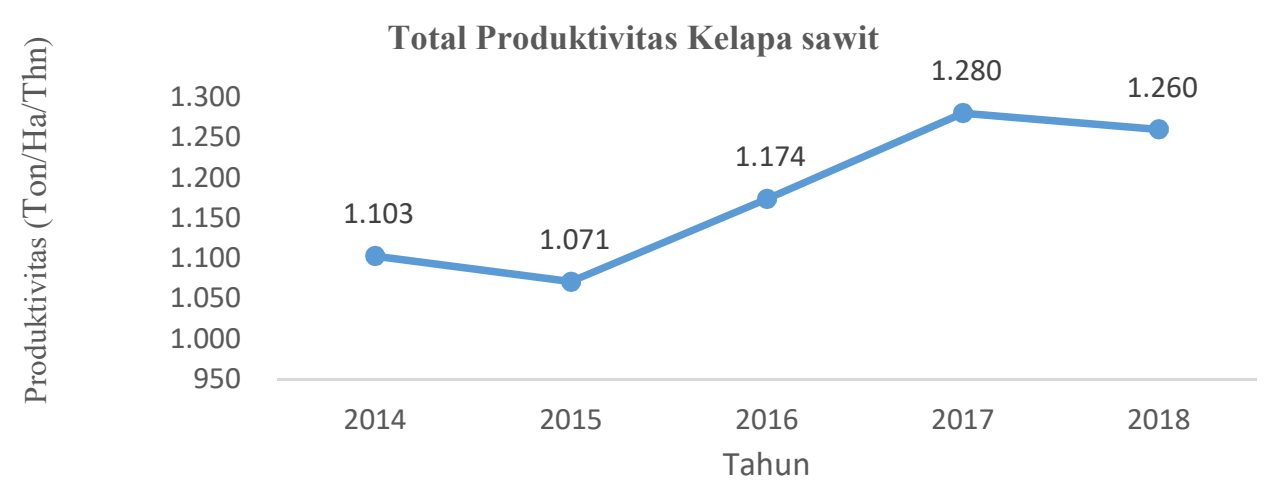

Gambar 3. Total Produktivitas Tanaman Kelapa Sawit Kebun Bah Birong Ulu PTPN IV Mulai Tahun 2014 - 2018

Gambar 3 menunjukkan bahwa produktivitas kelapa sawit tertinggi terdapat pada tahun 2017 yaitu sebesar 1.280 Ton/Ha/tahun, sedangkan produktivitas kelapa sawit terendah terdapat pada tahun 2015 yaitu sebesar $1.071 \mathrm{ton} / \mathrm{Ha} /$ tahun. Produktivitas kelapa sawit yang tinggi pada tahun 2017 dipengaruhi oleh jumlah produksi yang tinggi (21.331,98 ton/tahun) dan intensitas curah hujan yang merata sepanjang tahun. Produksi kelapa sawit, intensitas curah hujan dan hari hujan berkorelasi positif terhadap tingkat produktivitas kelapa sawit afdeling I Bah Birong Ulu.

\section{Realisasi Produksi Kelapa sawit}

Potensi produksi kelapa sawit dapat dicapai jika menggunakan kelas lahan yang tepat, benih kelapa sawit yang bermutu dan melaksanakan budidaya sesuai standar teknis berdasarkan kelas lahan dalam jangka waktu lebih kurang 20 tahun. Kebun Bah Birong Ulu menggunakan bibit yang berasal dari PPKS dan Socfin dengan tahun tanam 2004, 2005 dan 2006. 
Tabel 2. Perbandingan Realisasi Produksi Kelapa Sawit Dengan Potensi Produksi

\begin{tabular}{ccccccc}
\hline \multirow{2}{*}{$\begin{array}{c}\text { Tahun } \\
\text { Tanam }\end{array}$} & \begin{tabular}{c} 
TBS \\
\cline { 2 - 6 }$($ Ton/Ha/Thn)
\end{tabular} & $\begin{array}{c}\text { RBT } \\
(\mathrm{Kg} / \text { Tandan })\end{array}$ & $\begin{array}{c}\text { RJT } \\
(\text { Tandan } \\
\text { /Pokok })\end{array}$ & $\begin{array}{c}\text { TBS } \\
(\text { Ton/Ha/Thn })\end{array}$ & $\begin{array}{c}\text { RBT } \\
(\text { Kg/Tandan })\end{array}$ & $\begin{array}{c}\text { RJT } \\
\text { (Tandan/ } \\
\text { Pokok })\end{array}$ \\
\hline $\begin{array}{c}2004 \\
\text { PPKS }\end{array}$ & 27,60 & 30 & 9 & 28,50 & 24,80 & 8,70 \\
\hline $\begin{array}{c}2005 \\
\text { PPKS }\end{array}$ & 24,37 & 28 & 9 & 29,50 & 23,30 & 9,60 \\
\hline $\begin{array}{c}2005 \\
\text { SOCFIN }\end{array}$ & 23,34 & 28 & 8 & 29,50 & 23,30 & 9,60 \\
\hline $\begin{array}{c}2006 \\
\text { PPKS }\end{array}$ & 25,05 & 26 & 7 & 30,00 & 22,30 & 10,20 \\
\hline
\end{tabular}

Ket $:$ TBS $=$ Tandan Buah Segar $;$ RBT $=$ Rerata Berat Tandan $;$ RJT $=$ Rerata Jumlah Tandan

Tabel 2. menunjukkan bahwa realisasi produksi TBS dan RJT kelapa sawit di kebun lebih rendah jika dibandingkan dengan standar potensi produksi yang ditetapkan oleh perusahaan. RBT Realisasi produksi lebih tinggi jika dibandingkan dengan RBT Potensi produksi. Afdeling I kebun bah birong ulu berada pada ketinggian $650-870 \mathrm{mdpl}$.

$$
\text { Menurut Listi (2015), }
$$
peningkatan tinggi tempat menyebabkan perubahan produktivitas Tandan Buah Segar (TBS). Tinggi tempat yang optimal untuk memaksimalkan produktivitas kelapa sawit adalah 368 mdpl. Kenaikan tinggi tempat melebihi 368 mdpl justru menurunkan produktivitas.

\section{IV.KESIMPULAN DAN SARAN}

1. Produktivitas kelapa sawit tertinggi pada tahun 2017 sebesar 1.280 ton/ha/tahun dan produktivitas terendah tahun 2015 sebesar 1.071 ton/ha/tahun.

2. Realisasi produksi untuk TBS dan RJT kelapa sawit lebih rendah jika dibandingkan dengan potensi produksi. Sedangkan realisasi produksi untuk RBT lebih tinggi jika dibandingkan dengan potensi produksi.

Perlu dilakukan penelitian lanjutan mengenai faktor-faktor yang mempengaruhi produksi kelapa sawit dengan menambah variabel tenaga kerja, pupuk, herbisida dan factor lainnya yang dapat mempengaruhi produksi.

\section{DAFTAR PUSTAKA}

Direktorat Jenderal Perkebunan. 2016. Luas Areal Kelapa Sawit Menurut Provinsi di Indonesia, Menurut Pengusahaan 2015-2016. http://ditjenbun.deptan.go.id/ [15 desember 2018].

Fauzi, $d k k$. 2012. Kelapa Sawit (Budidaya, Pemanfaatan Hasil dan Limbah, Analisis Usaha dan Pemasaran). Penebar Swadaya. Jakarta.

Hakim. 2015. Kajian Produktivitas Tanaman Kelapa Sawit di Lahan Mineral dan Lahan Gambut Dengan Menganalisis Uji T. Test Dengan SPSS. PT. Cargil. 
Listi, E, $d k k$. 2015. Pertumbuhan, Produktivitas dan Rendemen Minyak Kelapa Sawit di Dataran Tinggi. Jurnal Ilmu Pertanian. Vol.18 No, 2 Hal : 77-83.

Pahan, I. 2008. Panduan Lengkap Kelapa Sawit (Manajemen Agribisnis Hulu hingga Hilir). Jakarta (ID): Penabar Swadaya

Simangunsong $d k k, 2005$. Trend Produksi Kelapa Sawit di Dataran Tinggi (Kasus Kebun Bah Birung Ulu, Sumatera Utara). Jurnal Warta PPKS 2005. 13(3): hal $1-6$.

Susila WR. 2004. Contribution of Palm Oil Industry to Economic Growth and Poverty Allevation in Indonesia. Jurnal Litbang Pertanian. 23(3): hal 107-114.

Yohansah dan Lubis. 2014. Analisis Produktivitas Kelapa Sawit (Elaeis guineensis Jacq.). PT. Perdana Inti Sawit Perkasa I, Riau. Institut Pertanian Bogor. 